\title{
RADIO FREE CUBA: FROM DÉTENTE TO RE-ESCALATION IN HAVANA AND MIAMI
}

\author{
Connor Harney \\ University of North Carolina at Greensboro, USA
}

Connor Harney is a PhD Candidate in History at the University of North Carolina of Greensboro. The focus of his work is transnational political economic histories of the 20th century, particularly those of the long 1970s. His research on Cuban-US relations examines how the island's pre-revolutionary ruling class has maintained hegemony within the exile community in Miami and influenced US foreign policy toward their former homeland

\begin{abstract}
While the United States long represented a safe haven for Cuban political exiles, the Cuban Revolution and its Cold War context accelerated the tendency of disaffected Cubans to flee the island for Yankee shores. As the main destination of those that left Cuba in the decades following the revolution, Miami and its émigré community played an increasingly important role in exile politics, and later US national politics. This article looks at how the first-wave of migrants to Miami established an outsized influence there and continued to dominate politically and culturally, even as subsequent waves representing more diverse perspectives on the Cuban Revolution set down roots in Florida. It does so by considering the attempts by one segment of the exile community to start a dialogue with the island during the Carter administration and another section's establishment of the propaganda station Radio Martí in Reagan years. These examples highlight the fluidity between political violence and softpower subversion in maintaining the hegemony of an antagonistic position to the Cuban Revolution.
\end{abstract}

Keywords: Cuban-US relations, Cold War, détente, hegemony, exile 


\section{Plastic Souls and Flesh-and-Blood Automobiles in New Old Havana}

In a brief moment of eased tensions between Cuba and the United States, the radical exile journal Areito (1978) felt emboldened enough to editorialise:

Miami now has the greatest concentration of Cubans in the world, Havana excepted. The dreams of bringing down Fidel have faded, but walking down Eighth Street one returns to the good old lost days. (Grupo Areíto 1978)

Further, as a simulacrum of pre-revolutionary Havana, they wrote that Miami was a town run by "bankers and mafiosi" where "blacks still know their place;" a city where "plastic souls and flesh-and-blood automobiles are manufactured" - a place where, "in the supermarkets, things buy people" (Grupo Areíto 1978). There is more than a kernel of truth to the idea that the Havana of old had been transplanted onto Florida shores after 1959, one that speaks to a broader relationship between Cubans in the United States and their former homeland. As María Cristina García (1998: 4) has written, the first wave of exiles biding their time in Miami believed "their stay would be temporary", since for the United States "to tolerate a communist government so close to its shores" would be counter to Cold War logic. Holding out hope, many became single-mindedly focused on ousting Castro as the key to turning back the clock to when all Cubans had been united, if only in their opposition to Batista.

To the cleanse the island of Castro's influence was seen as a "panacea for all ills" of Cuban society at home and abroad. Toppling him would free exiled Cubans to return home to their rightful place in Cuban society, before the revolution ruptured the previous social structure. In her article "Hardliners v. 'Dialogueros'", Cristina García (1998) presents this struggle for Cuba's future as roughly a generational one - with the first wave of Cubans representing those most opposed to the new order being constructed on the island, while younger Cubans, those that came of age in the United States or emigrated later, became gradually more open to reconciliation with the Cuban government. Groups that dissented from the hardline consensus of the Miami enclave were part of the generation that had "left one revolutionary state to enter another" (Cristina García 1998: 9). These Cubans went from a country in revolution to an America where large segments of the nation's youth had become animated by the black freedom struggle and the fight against the Vietnam War. In a world where the existing order seemed so uncertain on either side of the Straits of Florida, it makes sense that this later generation was more willing to 
compromise to build a relationship with the home that they had left behind, as they had very often departed at the urging of their families and with no choice in the matter.

While Cristina García acknowledges material differences between waves of emigration, the focus remains primarily the generational one between Cubans with the experience of youth during a time of rapid change playing the progressive role of resolving tensions between exiles and their former patría. There is certainly merit to this approach, and it is likely a factor in the increasing willingness of younger Cubans living in the United States to welcome warmer relations with the island, but it is not the whole story. It does not explain the persistence of hardline sentiment more than 61 years after the revolution. To understand this requires a return to an often-neglected class analysis of the Cuban Revolution and subsequent waves of emigration to the United States.

\section{Decadent Underdevelopment: The Limits of the National Bourgeoise}

Published in the same year that Fidel Castro would declare the Cuban Revolution a socialist revolution, Franz Fanon wrote extensively about the limits of the colonised national bourgeoisie in his seminal work, the Wretched of the Earth. His words on the topic reflect a great deal of the situation in Cuba before the revolution, and therefore, the trajectory of the Miami enclave. In the chapter on "the Pitfalls of National Consciousness", Fanon characterises the national bourgeoisie as deformed by colonial social relations to playing the role of handmaidens to foreign capital, whether they were under the thumb of a colonial power or not. The lack of nationally owned capital produced by conditions of underdevelopment were such, that, after the chains of colonial bondage were broken, "the national bourgeoisie steps into the shoes of the former European settlement", insisting "that all the big foreign companies should pass through its hands" (Fanon 1963: 152).

In so doing, Fanon argued that the national bourgeoisie "discovers its historic mission: that of intermediary" (Fanon 1963: 152). Rather than identify with an enterprising bourgeoisie of an earlier age, the colonial bourgeoisie had learned its lessons from a decadent bourgeoisie associated with the age of monopoly capitalism, ensuring that as a class it was "already senile before it" came "to know the petulance, the fearlessness, or the will to succeed of youth" (Fanon 1963: 153). Fanon then points out that there is a push "toward decadence" through the promotion of tourism by Western bourgeoisie, this tendency he contends was exemplified in Latin America. Havana in particular had been 
transformed into a den of debauchery and a playground for pleasure, a process helped along by a national bourgeoisie:

bereft ideas, because it lives to itself and cuts itself off from the people, undermined by its hereditary incapacity to think in terms of all the problems of the nation as seen from the point of view of the whole of that nation, the national middle class will have nothing better do than to take on the role of manager for Western enterprise, and it will in practice set up its country as the brothel of Europe. (Fanon 1963: 154)

This contention, that the character of the national bourgeoisie in colonised or postcolonial countries is particularly decadent, underpins Robin Blackburn's classic essay for the New Left Review, "Prologue to the Cuban Revolution". For Blackburn, the failure of Cuba's national bourgeoisie to move beyond their myopic vision of Cuban society in order to build institutions and a civil society that would at least on the surface appear to be for all Cubans, helped make the island ripe for revolution.

But it is not enough to acknowledge that a national bourgeoisie had a specific character, but there must be also a material explanation for that character. As Blackburn documents, after the onset of the Great Depression, $78 \%$ of Cuban sugar was milled by American-owned companies, one quarter of the land was owned by only four American firms and American companies invested just over $\$ 1.5$ billion in the island's economy. The dominance of US capital over the Cuban economy created conditions under which "the local landowning class" were "no longer supported or secured", that is, "the classic regime of landed oligarchy had failed to crystalize" (Blackburn 1963: 58-9). Even Cubanowned companies had to have their ownership qualified. For instance, as Blackburn pointed out among other examples, Bacardi was owned by two families: one of French and another of German origin (Blackburn 1963: 61). Another factor that he argued helped pave the road to revolution was the failure not only to build a strong tradition of parliamentarism, but even to construct political parties that might prefigure a more democratic future. Instead, this vacuum was filled by strange bedfellows, a young colonel of mixed ancestry and Cuba's Communist Party.

In his first term as President, Colonel Fulgencio Batista used the hollowness of Cuba's political system to try to mediate social strife on the island by making concessions to Communist-led organised labour. Indeed, the island's labour laws were "among the most advanced in Latin America" (Blackburn 1963: 72). However, when Batista took power by a military coup for a second presidential term, he was unable to recapture the same spirit that allowed his strange 
arrangement to tamp down social pressure. As Cuban society exploded in revolt against the growing contradiction between a desire for national public works and US ownership of the island's economy, Batista's regime became so "isolated" that it was only reinforced from within - a continuous cycle of resistance and repression ensured that it became an instrument of "pure terror and extortion" (Blackburn 1963: 72). It was in the years before the terror reached its zenith, that a young Fidel Castro led the now famous attack on army barracks in Moncada.

Speaking before a court poised to convict him, Fidel outlined a programme of revolutionary justice in "History will absolve me". In the speech, Castro put his finger on the pulse of dormant sentiment that had only just began to awaken among the Cuban people. Describing redistributive policies that were not out of line with those proposed by the abrogated Constitution of 1940 , he opened a festered wound that Batista's regime had sought to conceal through his previous capital-labour compact. Castro (1975) described the injustice of the Cuban justice system as imprisoning:

the poor wretch who steals because he is hungry; but none of the hundreds who steal millions from the Government has ever spent a night in jail. You dine with them at the end of the year in some elegant club and they enjoy your respect.

\section{Revolutionary Rupture and Continuity: Havana Moves to Miami}

In the time between his subsequent exile for the attempted insurrection at Moncada and his return with another small band of guerrillas in 1956, Castro's 26th of July Movement gained support, particularly in rural sections of the island, and only continued to garner more as they made their way through the Sierra Maestra mountains. It is this image of bearded guerrillas marching through the jungles of Cuba that has become so synonymous with the Cuban Revolution. However, in his recent work, A Hidden History of the Cuban Revolution, Steve Cushion challenges the traditional view of the revolution's base of support and the singular importance of the guerrilla struggle to its success. For the most part, the movement to overthrow Batista has been portrayed as a movement of white-collar professionals, intellectuals and the rural peasantry, while the urban proletariat came late to the game - landing the final death blow to the regime with a failed general strike in 1958. Using previously unreleased Cuban sources, Cushion (2016: 213) highlights the role of militant union rank-and-file, who despite the conservatism of their leadership and the repressive nature of military rule managed "to build a clandestine labor movement". 
His work helps illustrate the class composition of the Cuban Revolution's base of support, and challenges the notion that the revolution's turn to radicalism was manufactured from above by leaders like Ernesto "Che" Guevara, as well as Fidel and Raúl Castro. Cushion's work complements the earlier groundbreaking work of Julia Sweig, which focused on the role of the urban underground in the coalition that made up the 26th of the July Movement. In particular, rather than as tool to discredit the underground by Castro and crystallise the dominance of the guerrillas of the Sierra over the movement, the strike was presented by llanos (urban underground members) as an alternative to a reliance "on violence and sabotage to unseat the dictator" (Sweig 2004: 11).

Equally important to understanding the class basis of support for the revolution is understanding the composition of its detractors. With its unique proximity and status as an exile enclave, Miami represents an important geographic case study to understanding developments in the émigré community that can highlight this opposition that fled rather than remained on the island. While exoduses have often followed social revolutions, Cuba's close geographic position to United States' orbit made the pull particularly appealing for a number of reasons, including both familiarity and political expediency. As opposed to the largely popular base of support for the revolution, particularly in the early years, those opposed to the radical transformation of Cuban society were drawn from elite segments of the population. Absent from much of the literature is a structural class analysis of what that has meant for the development of the émigré community in Miami, and while many have attempted to include that analysis into their larger understanding of the experience of Cubans living in exile, most attempts have been superficially descriptive rather than analytical. Working within the framework of class as a relationship to the means of production, more plainly the ability to plan and oversee production and distribution within a national economy brings a depth of clarity to how Cuban émigrés have related to their former patria and their new home in the United States - more so than one that relies solely on levels of income.

Yanna Yannakakis' recent work on colonial Oaxaca offers an interesting corollary to understanding this class relationship within a larger colonial context. She describes the dual pressures from above and below felt by indigenous intermediaries in administrating empire. While the scope of Yannakakis' project may not have had to contend with a more fully developed form of capitalism; her primary focus is on the borderlands of the Spanish empire in what is now Mexico, meaning a region not easily directly administered by the Spanish themselves, requiring indigenous intermediaries to maintain sovereignty. Despite the difference in political economic systems, and the almost five-century gap between examples, the lens she offers highlights the tensions that existed between the 
Cuban ruling class and the Cuban people. Indeed, she describes the maneuvering required by her native intermediaries to "appeal to at least two audiences who were often at odds", and much the same can be argued for Cuban elites' relationship to their American counterparts and the working Cubans they employed (Yannakakis 2008: 13). This arrangement became increasingly clear as the turbulent 1960 s came to an end, and with them, most of the outright political violence perpetrated by CIA-sanctioned exile terrorist organisations. The $1970 \mathrm{~s}$ and 1980s instead saw a shift toward working within the United States and its political system to undermine the Communist regime in Cuba. Working toward this aim required consensus building within the state and the business community, while simultaneously maintaining hegemony within the enclave community in Miami.

This method of analysis allows Cuban exile elites to remain agents, exerting pressure on the United States government to get tough on Cuba and maintaining a strong hold on "common sense" within the émigré community, but at the same time, understanding the very real structural barriers that existed. No longer able to court overt counterrevolution through political violence, many turned toward alternative methods to elicit their desired outcomes by working through their adoptive home's political system. In working to overthrow the Communist government through political organising, Cuban exiles became an important constituency for a reinvigorated Republican party. In the process of courting these new benefactors they were often allowed near the levers of political power. What this meant in practice was that policy victories like the greenlighting of Radio Martí, a station that broadcasts anti-communist propaganda to the island from Miami, represent less a triumph of exile organisations like the Cuban American National Foundation (CANF), and more a confluence of interests between Cuban elites and their counterparts in the Reagan administration. Viewed in this light, their influence appears less as hijacking American foreign policy, and more as the convergence around class interests - one subject to change as material conditions shift over time.

\section{From Resistance to Batista's Terror to the Terrorism of Cubans in Miami}

While the intention here is to emphasise the role of hegemony over force in the maintenance of class, any attempt to understand the Miami enclave must at least grapple with the reality of exile terrorism. Largely, the argument for recourse to soft power over hard power is that the influence of the already existing civil society and political culture in the United States tempered the tendency toward the blunter instrument of counterrevolutionary terrorism. However, as Lourdes 
Arguelles has countered, the very existence of the American national security state represents a negation of the norms and procedures established by the political and civil institutions of the United States. Highlighting the long relationship between Cuba and the larger project of maintaining the US empire abroad, Arguelles explains that Cuba became the "preferred site for the testing of the repressive technologies of the US national security agencies" (Arguelles 1982b: 291). Reflecting their junior partner status, however, Cubans themselves were not typically selected for intelligence work until after the revolution. Later, with the ouster of Batista, and the subsequent failed Bay of Pigs invasion, the national security state was relieved of any reluctance toward using Cubans in their schemes to remove Castro from power.

The failure of Operation Mongoose, a state-sanctioned campaign of counterrevolution, ensured a cadre of trained anti-communist paramilitary fighters were left to scatter to the wind after it no longer seemed a viable solution to regime change. Arguelles places these former exile assets in three categories: those that wanted to be recalled to work for the CIA, those that wanted to retire from that line of work and find more lucrative employment in organised crime and as mercenaries, and finally, those that became opposed to both the American national security state and the Castro regime (Arguelles 1982b: 296-9). Indicative of the latter is the infamous Orlando Bosch, who helped perpetrate the bombing of Cubana Flight 455 and the killing of Chilean exile statesmen Orlando Letelier. These acts were committed by the umbrella-exile organisation CORU (Coordination of United Revolutionary Organisations), whose raison d'être was to topple Castro and fight communism regionally by any means necessary. The founding of this, Arguelles called Bosch's "most important accomplishment to date", despite the gravity of the above violence (Arguelles 1982b: 300). In a more recent article by historian Alan McPherson, Bosch and his compatriots are again provided as examples of exile terrorism to illustrate a larger point about the recourse to violence. That is, central to the ideology of terrorism that places Cuban exile terrorists on similar footing to groups like the Taliban is the belief that all other options to achieve a political end have been exhausted, and that violence remains the only one (McPherson 2019: 394).

McPherson utilises this ideological criterion and two others to make the comparison to the Taliban, because it helps "explain" the "radicalization" and "resonance among the surrounding community", as well as "the power of Cuban American politics to resist change and to gridlock American national politics and U.S.-Cuban relations for decades" (McPherson 2019: 391). In a sense, both commenters see unity as central to the story of terrorism's link to the Cuban émigré community, for Arguelles, that of organisational accord, and for McPherson, an implicit ideological agreement amongst exile terrorists. Such a 
view assumes a level of coherence both ideological and organisationally amongst the most radical fringes of the émigré community, one that does not exist outside of anti-communism, and more importantly, it assumes that fear of violence serves as the only motivator of peoples' actions and identity, an inversion of the very same logic applied by opponents of the regime in Cuba.

Indeed, in service of his argument about the conservative character of the exile enclave, McPherson claims that 53\% of Cubans in Miami remained opposed to normalising relations with the regime in Havana. In doing so, he fails to mention that the other $47 \%$ were open to other options. All this from a poll conducted by the Miami Herald (published 29 December 1975), only a year before Bosch's attack on the Cuban airline. This is not to detract from the importance of terrorism and its role in shaping "common sense", but more to say that it should not be reduced to the sole or even most important factor. More important, and even supported by Arguelles' own work, is the experience of everyday life. In particular, that of education, work and family life, all which are crucial to the formation of individual identity and the relationship of the individual to the large structure of society. As Arguelles highlights, the tendency of Cuba's national bourgeoisie to invest in the mainland over their homeland made the transition from Havana to Miami a less difficult one after the revolution. In the process, transforming the former by "cosmic drama" into

a fascinating mélange of the activities that identified the Havana of yesteryear, interwoven with elements planned by Miami's city fathers in the 1940s and 1950s and with other byproducts of the mainland culture. (Arguelles 1982a: 28-32)

At the same time that this bourgeoise was transforming their new surroundings, they found themselves transformed by their adoptive home. Many of those that had once found themselves among Cuba's middle class were not so lucky, and slowly slipped into the working class. This proletarianization is reflected in the fact that, by $1982,82.6 \%$ of Cubans in Dade County were direct production workers compared with $29.3 \%$ that were employed in that work back in Cuba (Arguelles 1982a: 34). To solace these declassed Cubans was what Arguelles describes as a "propaganda machine" bent on "the creation of pseudo needs, both emotional and material"; an ideological state apparatus that glamorises the accoutrements of consumer society: TVs, automobiles, etc., all of which come along with a set of "consumer practices", not the least of which is "an astronomical level of consumer indebtedness" (Arguelles 1982a: 39). Such an Althusserian inflected view provides a certain explanation for the predominance 
of hardline anti-communism in Miami's émigré enclave, but at the same time that it provides explanatory power, it also removes human agency, or at least most human agency. Instead, Antonio Gramsci's conception of hegemony as something contested within civil society provides a framework that accounts for the "propaganda machine", but in a way that reflects the role of human action, no matter how unequal the field of play may be. Specifically, there is room to put forward views that challenge the "common sense" of the community, but the transmission and legitimacy of those views are deeply intertwined with private ownership of the means of communication, or put another way, the capacity of individuals or groups to circulate new ideas.

\section{Class Composition of the Exile Community across Time}

For Cubans as far back as the struggle for independence from Spain, the United States had long been a destination to escape political and social upheaval, but the uptick in migration and the acceleration of that process wrought by the fight against the Batista regime and the Cuban Revolution cannot be understated. In 1958, 70,000 born on the island resided in the United States, by the census of 1980 , that number had grown to 803,226 , not including the 125,000 that would migrate though the Mariel Boatlift only a few months later (Lisandro Pérez 1986: 127). Not surprisingly, most of those who immigrated from 1959 onward, relocated to an urban area in the United States, 52\% ended up in Miami alone (Lisandro Pérez 1986: 130). Owing to the uneven geographic development of Cuba and the relatively privileged status of Cuban exiles, most emigrated from Havana even into the 1980 s, with almost $64 \%$ of respondents in interviews conducted between 1976 and 1979 departing directly from the nation's capital. Particularly of interest in understanding these émigrés' class status is their occupations before they left Cuba. Of those that chose to leave in the first wave of emigration from the island in the late 1950s and early 1960s, nearly $40 \%$ were proprietors, managers or professionals, at a time when these made up only $10 \%$ of the total population. This overrepresentation of elites compared to their actual percentage of the population as a whole may be even more disproportional - considering the occupations of émigrés were not registered until 1961 (Bach and Portes 1985: 145).

Initially, these wealthy exiles sought to restore their former status on the island by either directly leading or funding adventurist expeditions of political violence, but as that strategy proved to yield less than stellar returns on investments, they shifted gears. That meant making themselves at home in the United States, so as to regroup. Effectively, that meant establishing hegemony in the enclave community. Advocating for special status for Cuban immigrants to the 
US and funding charity to establish their import within the community, these elites reasserted their position within their adoptive homeland. Within the Cold War context of their immigration, policies like the Cuban Adjustment Act created a unique pathway to citizenship that favoured Cubans over other immigrants from Latin America. It allowed Cubans to receive US citizenship within two years of entering the country, a policy that helped elite Cubans more easily establish their base of support and ensured that others would tread the same path as a means of resistance to the revolution. At the same time, the Cuban Adjustment Act was not the solely the product of Cuban lobbying, but rather a tried and true tool in the US policy toolbox during the Cold War, one used against other Communist regimes. ${ }^{1}$ Regardless of which party deserves more credit, the magnetic pull that this policy had long provoked a response from those back on the island who saw the policy as simply another attack in a long line on their national sovereignty. Indeed, as pre-eminent scholar of Cuba, Rafael Hernández (1985: 10) wrote in the American Maoist journal Line of March, US immigration policy toward Cuba historically "exploit[ed] immigration and us[ed] it as an aggressive propaganda tool". ${ }^{2}$

Attempts to use immigration to pull Cubans away from support of the revolution were not without repercussions, both for the United States and the Cuban enclave in Miami. The Mariel Boatlift, a mass exodus of Cubans to Florida shores that occurred in response to rising social pressures in Cuba and coincided with a breakdown in dialogue with United States, represents just such a moment. After Cubans seeking asylum in South America drove a bus through the gates of the Peruvian Embassy in early 1980, killing a Cuban guard in the process, the Cuban government announced that it would allow people to leave through the embassy turned encampment. These Cubans would be processed in Costa Rica and sent to their respective destinations. Press coverage celebrating this movement of peoples pushed the Cuban government to increase the flow of emigration from a trickle to a tidal wave. Using the previous years' open lines of communication with the mainland, the Cuban government decreed that anyone that wished to leave for United States and had a means of transport could depart from the Port of Mariel. As noted above, almost 125,000 crossed the Straits of Florida in this way, travelling on vessels that ranged from borrowed yachts to ramshackle boats hardly built for the journey.

1 H.R. 15183 1966, Session of November 2. Available at: http://uscode.house.gov/ statutes/p1/89/732.pdf.

2 For a full account of the New Communist Movement in the United States, of which Line of March was a part, see Elbaum, Max, (2018) Revolution in the Air: Sixties, Radicals Turn to Lenin, Mao and Che. 3rd ed. (New York: Verso). 
The effect of this wave of emigration on the Miami enclave cannot be underscored enough, almost overnight the new arrivals changed the city's demographics. Marielitos by and large tended to be more non-White than previous waves of Cuban emigrants, reflecting the actual racial composition of the island. Compared to the first wave of emigration to the United States after revolution, less than $15 \%$ of Mariel Cubans were professionals, and in fact, the majority were employed as manufacturing or agricultural labourers, or service workers. Both of these factors taken together are an excellent indicator of the difference in class between Marielitos and previous waves of emigration: the obvious differences in occupation, but more subtly, the racialised nature of class in Cuba, help explains the discrepancy in outcomes for Marielitos in the United States.

Those that arrived tended on the whole to have a more difficult time getting a job. With an unemployment rate of $27 \%$ among Marielitos, these new arrivals were three times less likely to find a job than the rest of the Cuban population had been able to before the boatlift. Mariel Cubans were also more likely to live in unstable households because of their more dire economic situations, which was further compounded by a lack of familial and friendship networks that could relieve the worst of their precarity. Among other distinctions from previous waves of immigration, these émigrés were more likely to have a lower command of the English language, to live in poverty and less likely to have achieved higher levels of education ten years after they left Cuba (Fernández 2007: 6057). Gastón Fernández (2007: 620-1) asserts that these difficulties of integration were the product of a stigma produced by perception and the portrayal of Marielitos in both Cuba and the United States. According to Fernández, this process is helped along by the media and the state, whose role it is to aid in ascribing identity to immigrants. While there is no doubt that the media and the state play a role in creating identity categories, there is a problem with viewing class purely as an identity, as it removes the relation to the material that underpins the social relations of class. A materialist conception of class would argue that those that helped construct the Marielito stigma did so by leveraging their own access to wealth and political power, and that along with this cultural stigma, their own class background limited the economic horizons in a way that it had not for previous cohorts.

\section{Dialogue as Détente}

To see clearly how a certain idea of what it meant to be Cuban in the United States became hegemonic requires a link between cultural struggles and economic ones. In this case, an attempt to break with that hegemony before Mariel and its restoration after illustrates this contentious nature of "common sense". 
Beginning in the 1970s, there was an attempt to upend enclave hegemony by a group of young Cuban émigrés who had come of age and participated in the social upheaval of the 1960s. One such group was the Antonio Maceo Brigade, an organisation made up of Cubans who had immigrated to the United States at the behest of their parents. They remained curious to see the changes made to their former home by the revolution they fled. Taking part in a series of excursions to visit family and learn about the transformation of the island, as well as functioning in an extremely limited diplomatic capacity, these idealistic mariposas were an important part of El Diálogo - an informal exchange between the United States and Cuba meant to patch frayed relations at the tail end of the Carter administration. ${ }^{3}$ Highlighting the heady idealism of the period, Brigade member María de los Angeles Torres (2001: 9) recalled that "everything looked beautiful, even the young military guards posed with shiny rifles whose job it was to guard the Palace of the Revolution from us". While the reality of the situation soon dashed some of the intense optimism toward the process of reconciliation between the émigrés and their former homeland, the foundation built by this brief opening proved unknowingly pivotal. Unfortunately, the reverberations of this process would not be felt for many decades. For many at the time, El Diálogo simply ended with disappointment, and for a tragic few, trauma and even death.

Part of the excitement felt by the Antonio Maceo Brigade was the perception that they were shrinking the long 90 miles that separated Cuba and the United States, but as it turned out the emblematic victory of their trips - the release of political prisoners long held in Cuban jails - had been brokered months before by representatives of the State Department and the prominent exile banker Bernardo Benes. The seeming correspondence of the prisoners' release with their visits was simply a coincidence, rather than a product of the delegation's efforts. Chief of Mission of the Cuban Interests Section, Wayne Smith (1987: 163), bemoaned that the whole thing “appeared to be a gesture on Castro's part to them, not at all a result of Carter's human-rights policies”. Despite the limited gains of the group at that moment, they represented enough of an ideological threat to the hegemonic position of staunchly conservative elements in the enclave community to receive significant backlash for their efforts. As Smith (1987: 162) recalled in his memoirs, back in Miami, "several committee members were set upon and beaten. The lives of others were threatened, and one was in fact murdered." Indeed, in 1978, Carlos Muñiz Varela was tragically

3 Mariposas or butterfly was the term given to these Cubans by those they visited on the island, an endearing departure from the pejorative term gusano (worm) that was previously used to describe the exile community in Miami. 
assassinated outside of the travel agency he set up in Puerto Rico to assist exile travel to Cuba. ${ }^{4}$ Even Benes, a moderate figure in the Miami enclave, found himself the target of intense scrutiny from the local media which christened him a communist traitor for his activities in trying to restore relations between the United States and Cuba. Not only was he publicly shamed, but his bank was bombed, and in an interview in 1994, he recalled "for a year he wore a bulletproof vest” (Bardach 1994: 23).

\section{Radio Free Cuba: Conservative Hegemony Restored}

This surge in terrorist activity, comparable to that which arose at the height of Operation Mongoose, occurred at a time when as the Cuban newspaper Granma aptly opined the exile leadership feared "losing control of the situation" in Miami. Just as important as these acts of terror to reasserting their status, was the manoeuvring and jockeying for position within the American political system (Granma Weekly Review 1980: 7). The linchpin to that strategy meant playing American politics by understanding the rules of the game. CANF, founded by millionaire Jorge Mas Canosa in the wake of the brief opening under the Carter administration, sought to wield the wealth of exile elites to maintain their position within the enclave community, and hopefully, ensure a seat at the table after what they believed to be the inevitable fall of communism in Cuba. The organisation helped fund elections for both Democrats and Republicans to ensure that candidates took a strong stance on relations with Cuba. Between 1983 and 1988, the Free Cuba PAC was responsible for \$385,000 in donations to campaigns - two of these politicians, Democrat Lloyd Bentsen and Republican Dan Quayle, went on to become vice-presidential candidates in 1988 (Cristina Garcia 1996: 147-50). Along with influencing elections, CANF helped create and lobby for strong anti-communist foreign policy. Radio Martí was one such policy. The brainchild of Mas Canosa, it sought to prey upon the discontent he observed among the Marielitos. Envisioned as radio station that would broadcast programming critical of Castro in a way that those socialised by the revolution would find appealing, he proposed the idea on 3 November 1980 (Cull 2008: 407).

It would be very easy to conflate the eventual adoption of Mas Canosa's proposal simply as a victory for him and his organization, but even the initial title of the station "Radio Free Cuba" illustrates the level of influence of US elites. The name was a nod to Radio Free Europe/Radio Liberty, a station that had long

4 For a more in-depth account of not only the killing of Varela, but the Antonio Maceo Brigade see Latner 2018. 
broadcast anti-communist propaganda to Eastern Europe. Even before the launch of Radio Martí, pro-American propaganda saturated the airwaves, one study commissioned by the United States Information Agency found that across Latin American a total of 1,054 hours of programming were broadcast by "free world" or "Western" stations. ${ }^{5}$ With all the programming already being beamed toward the island, many were sceptical about the need to create a separate platform directly designed to appeal to Cuban dissidents - for that reason it floundered in Congress - but eventually received the go ahead in March 1981. Ultimately, Radio Martí went online on 20 May 1985, a day after the centennial of Martí's death and the 83rd anniversary of the end of US military occupation.

Highlighting the difficulty in placing the locus of influence, on either the US or Cuban Americans, is a work published by the liberal security thinktank, the RAND corporation. The work, A Strategy for Dealing with Cuba in the 1980s, was published three years prior to the first broadcast by Radio Martí, and written by a Cuban-born analyst Edward Gonzalez. According to Gonzalez, Cuba represented the number one threat to the United States' influence in the Caribbean Basin. He argued that the success of the Sandinistas in Nicaragua and the New Jewel Movement in Grenada were due to Cuba's exploitation of the situations there for its own ends, rather than the culmination of those countries' own internal social dynamics (Gonzalez 1982: 12). For Gonzalez, rapprochement had been an abject failure based on a faulty premise that Cuban motions toward peaceful coexistence were anything more than empty gestures to pacify the regime's critics. Instead, he claimed that there needed to be a "domestic consensus . . . nourished and maintained by one U.S. Administration to the next" in order to establish "sufficient support for sustained pressures against Cuba during the course of the 1980s" (Gonzalez 1982: 38-100). One of Gonzalez's consensus-building plans was to use mass media in the form of a radio station to send a clear message from the mainland to Cuba, one that he believed would cut through the static of the island's "pedantic, selective, and politicized" state media (Gonzalez 1982: 113).

Gonzalez's plan for programming was to provide:

a weekly analysis of the regime that employed a Marxist framework and that focused on the "new class" emerging in Communist Cuba, and the evidence of continued "class struggle" and exploitation" under the Castro regime. (Gonzalez 1982: 118)

5 "Communist International Radio Broadcasting to Latin America and North America Decreased in 1983-84", S-1-14-86, Identifier: 5684701, Container: 48, NACP. College Park, MD, 14 January 1986. 
This plan was not altogether different from what Radio Martí eventually became. What makes the case of this strategy and Gonzalez as individual so interesting is that they embody the interconnectedness between segments of the Cuban exile population and those at the commanding heights of political economic power in the United States. The influence of Cuban Americans like Gonzalez was not a one-way street. Embedded in the RAND Corporation, there is no way that he would not have imbibed, at least a residually, the Cold Warrior mentality that permeated this thinktank of the national security state. While his motivations for taking on such a line of work may have been instrumental, individuals are just as much transformed by the institutions they find themselves in as they are successful in transforming those same institutions.

At the same time, in recommending that there be an agreement around what should be done about Cuban/US relations, Gonzalez seems to have been very well aware of limitations of individuals and the influence of institutions, if only in an ideologically bounded sense. Indeed, if a hardline approach to the island were to be maintained, a principle that cohered the Cuban community together was necessary. Gonzalez clearly believed that working to influence Cuba's culture from abroad could be such a strategy for unity. Daniel Walsh's An Air War with Cuba shows the relative merit to Gonzalez's assumption. He argues that Radio Martí acted as glue that held together disparate opposition groups in the Cuban exile community, which it achieved by providing a concrete task to work toward outside of the long-term goal of removing Castro from power. While he contends that Radio Martí brought these elements together, their own attempt at independence from Voice of America was a double-edged sword, as it allowed those involved with the station's operation to curate content directly applicable to Cuba, but their time removed from the island meant that their understanding of the changes wrought by the revolution was incomplete at best. Such a view was verified by scholars just prior to when Radio Martí began its operations.

Only a year after the station began broadcasting to the island, two scholars specialising in the medium conducted an independent review of the platform. The thrust of their criticism confirmed many of the initial concerns about programming, suggesting that the station supplement its rotation with content created for Voice of America. More importantly, both men showed concern for the lack of oversight of the station. Unlike VOA or Radio Free Europe, the research conducted to put together programming for Radio Martí was not done independently, which they asserted risked 'either positive or negative bias in responses, depending on what the interviewee thinks of the organization sponsoring the research" (Boyd and Straubhaar 1986: 21). To Boyd and Straubhaar, it represented a potential bias 
in programming and the creation of an insular feedback loop between the audience and the programming creators. The logic followed that exiles - desiring to flee their homeland for a multitude of reasons - did not represent the listeners who may or may not have wanted to remain there (Boyd and Straubhaar 1986: 22-3). In light of that criticism, the reviewers recommended that the interviews be conducted with exiles that chose a different adoptive homeland than the United States, and if possible, interview Cuban travellers abroad rather than exiles (Boyd and Straubhaar 1986: 24).

\section{Conclusion}

These recommendations cut to the heart of the intent of a propaganda station like Radio Martí, as it is clear the producers never sought a balanced appraisal. From its inception, the station was seen as a means of shifting culture on the island to more closely align with that in Miami, a culture founded on social relations not unlike those found in pre-Revolutionary Cuba. While supporting a long-term strategy like the kind of social engineering that Radio Martí reflected, it showed the marked change in tactics of the exile ruling class. Resigned to the likelihood that the Cuban Revolution had won in the short term, they would overtly continue to call for the overthrow of Castro by any means necessary, but in practice support policies like the tightening of the embargo and other outstanding sanctions against Cuba, and of course Radio Martí. In a sense, the Cuban ruling class had temporarily given up the Gramscian war of manoeuvre for the long-term war of position. However, the ease with which they moved tactically between political violence and propagandising highlights the dialectical relationship between both types of warfare - that is, the importance of winning the hearts and minds of people until the strength of force is enough to vanquish one's enemies (Gramsci 1971: 108).

By utilising the American political system and embedding themselves in the beltway milieu, they legitimated themselves in the same way they had in Cuba before 1959. This meant leveraging their outsized influence gained from their relationship to the American ruling class, a product of the intimacy shared through the bonds of class solidarity. Rather than a rupture, the growing space for Cuban elite politicking embodied a continuation of the relationship they had with their American counterparts before the revolution. Cuban elites would rather bide their time for a chance to reinstate the Ancien Régime on island than engage meaningfully with a society that has long since left them behind - it is this contradiction that helps explain the continued antagonism between Cuba and the United States on the international stage. 


\section{References}

Arguelles, Lourdes (1982a) "Cuban Miami: The Roots, Development, and Everyday Life of Emigré Enclave in the U.S. National Security State", Contemporary Marxism, 5, 27-43. Available at: http://www.jstor.com/stable/29765699 (Accessed 29 August 2020).

Arguelles, Lourdes (1982b) “The US national security state: the CIA and Cuban émigre terrorism", Race and Class, 18(4), 287-304.

Bach, Robert L. and Portes, Alejandro (1985) Latin Journeys: Cuban and Mexican Immigrants in the United States. Oakland, CA: University of California Press.

Bardach, Ann Louise (1994) "Our man in Miami," New Republic, 211(14), 20-5. Available at: http:///proquest.com/docview/212881963 (accessed 26 August 2020).

Blackburn, Robin (1963) "Prologue to the Cuban revolution", New Left Review, 0(21), 52-91.

Boyd, Douglas A. and Straubhaar, Joseph (1986) "Independent 1986 Evaluation of Cuba Service - Radio Martí Program, Voice of America, USIA”, 17 May, S-5-0-86A, Identifier: 5684712, Container: 48, NACP. College Park, MD.

Castro, Fidel (1975) "History will absolve me", trans. Pedro Álvarez Tabío and Andrew Paul Booth. Havana: Editorial de Ciencias Sociales. Available at: https://www.mar xists.org/history/cuba/archive/castro/1953/10/16.htm (accessed 20 August 2020).

Cristina Garcia, María (1998) “Hardliners v. 'Dialogueros': Cuban Exile Groups and the United States-Cuba Policy”, Journal of American Ethnic History, 17(4), 3-28.

Cull, Nicholas (2008) The Cold War and the United States Information Agency: American Propaganda and Public Diplomacy, 1945-1989. New York: Cambridge University Press.

Cushion, Steve (2016) A Hidden History of the Cuban Revolution: How the Working Class Shaped the Guerrillas' Victory. New York: Monthly Review Press.

de los Angeles Torres, María (2001) In the Land of Mirrors: Cuban Exile Politics in the United States. Ann Arbor: University of Michigan Press.

Fanon, Franz (1963) The Wretched of the Earth, trans. Constance Farrington. New York: Grove Press.

Fernández, Gastón (2007) “Race, gender, and class in the persistence of the Mariel stigma twenty years after the exodus from Cuba", International Migration Review, 41(3), 602-22. Available at: http://www.jstor.com/stable/27645686 (accessed 8 September 2020).

Gonzalez, Edward (1982) A Strategy for Dealing with Cuba in the 1980s. Santa Monica, CA: RAND Corporation.

Gramsci, Antonio (1971) Selections from the Prison Notebooks, ed. Quintin Hoare and Geoffrey Nowell Smith, 1st ed. New York: International Publishers.

Granma Weekly Review (1980) "Cubans Living in the United States Subjected to Ideological Oppression”, 15(9), Havana, 9 March.

Grupo Areíto (1978) Contra Viento y Marea. Havana: Casa de las Américas.

Hernández, Rafael (1985) “U.S. Cuban policy and the Cuban community question”, Line of March: A Marxist-Leninist Journal of Rectification, 18, 9-28. 
Latner, Teishan A. (2018) Cuban Revolution in America: Havana and the Making of a United States Left, 1968-1992. Chapel Hill, NC: University of North Carolina.

Lisandro, Pérez (1986) "Cubans in the United States”, Annals, 487. Available at: http:// www.jstor.com/stable/1046058 (accessed 20 August 2020).

Smith, Wayne (1987) The Closest of Enemies: A Personal and Diplomatic Account of U.S.-Cuban Relations since 1957. New York: W.W. Norton \& Co.

Sweig, Julia (2004) Inside the Cuban Revolution: Fidel Castro and the Urban Underground. Cambridge, MA: Harvard University Press.

Walsh, Daniel C. (2012) An Air War with Cuba: The United States Radio War Against Castro. Jefferson, NC: McFarland \& Co.

Yannakakis, Yanna (2008) The Art of Being In-Between: Native Intermediaries, Indian Identity, and Local Rule in Colonial Oaxaca. Durham, NC: Duke University Press. 